\title{
Understanding the Symbolic of Lotus Flower in Teratai: A Process of Transferring the Lyrics and Rasa (Feeling)
}

Nur Nafishah Binti Azmi, Noor Zahara Suryani Binti Abdul Razak, Wan Ainaa Atiqah Binti Mohd Ismadi

To Link this Article: http://dx.doi.org/10.6007/IJARBSS/v11-i1/8415

DOI:10.6007/IJARBSS/v11-i1/8415

Received: 10 November 2020, Revised: 03 December 2020, Accepted: 25 December 2020

Published Online: 12 January 2021

In-Text Citation: (Azmi et al., 2021)

To Cite this Article: Azmi, N. N. B., Razak, N. Z. S. B. A., \& Ismadi, W. A. A. B. M. (2021). Understanding the Symbolic of Lotus Flower in Teratai: A Process of Transferring the Lyrics and Rasa (Feeling). International Journal of Academic Research in Business and Social Sciences, 11(1), 106-113.

Copyright: (c) 2021 The Author(s)

Published by Human Resource Management Academic Research Society (www.hrmars.com)

This article is published under the Creative Commons Attribution (CC BY 4.0) license. Anyone may reproduce, distribute, translate and create derivative works of this article (for both commercial and non-commercial purposes), subject to full attribution to the original publication and authors. The full terms of this license may be seen at: http://creativecommons.org/licences/by/4.0/legalcode

Vol. 11, No. 1, 2021, Pg. 106 - 113

Full Terms \& Conditions of access and use can be found at http://hrmars.com/index.php/pages/detail/publication-ethics 


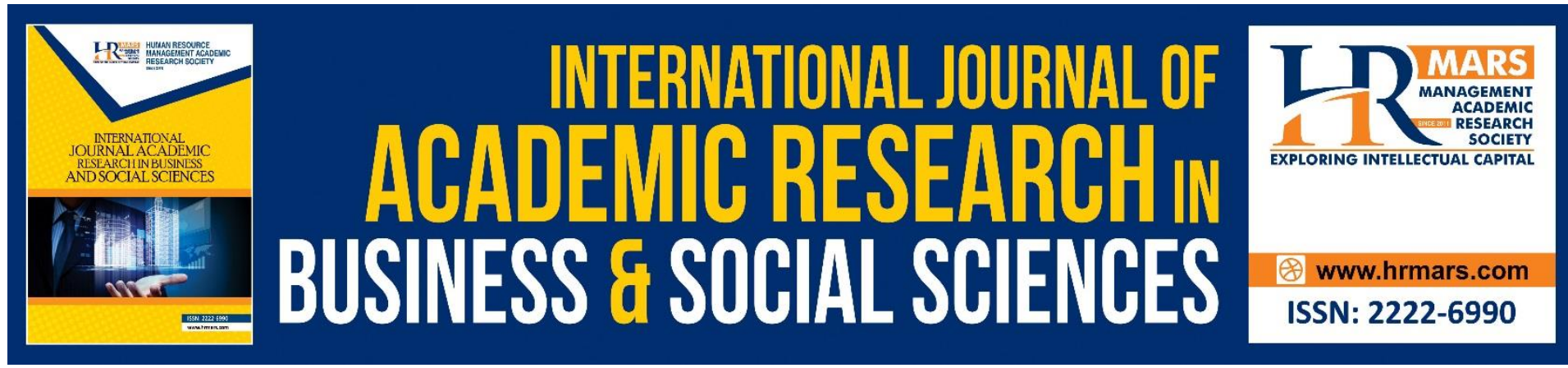

\title{
Understanding the Symbolic of Lotus Flower in Teratai: A Process of Transferring the Lyrics and Rasa (Feeling)
}

\section{Nur Nafishah Binti Azmi, Noor Zahara Suryani Binti Abdul Razak, Wan Ainaa Atiqah Binti Mohd Ismadi}

Faculty of Film, Theatre and Animation, Universiti Teknologi MARA (UiTM), Selangor Branch, Puncak Perdana Campus, 40150 Shah Alam, Selangor.

Email: nafishah2610@uitm.edu.my,zara.suryani@gmail.com, ainaatiqah88@gmail.com

\begin{abstract}
The Malay culture is very rich and closely related to traditional beliefs and practices. The philosophy is the outcome of the daily thinking processes that take place in the human's intellect ('aqal). The teratai (trans. lotus flower) is seen as a symbol that holds diverse philosophical meanings in the Malay culture and thought. This research is conducted to understand, explore and experience these meanings focusing on the philosophy and symbolism of the lotus in the Malay thought. The symbols of lotus are closely associated with the meaning of budi (intelligence/reason). These symbols include the enlightenment and selfregeneration as part of the process to reach the state of divinity in life. The morphology of the lotus reflects the human soul in pursuit of the sublime as the destiny of every man (insaan). In order to comprehend the reality (hakikat) of the Malay thought, one needs to 'experience' the actual meaning of lotus. This research concludes that a man (insaan) reaches a state of divinity once the person understands the philosophy of the lotus.
\end{abstract}

\section{Introduction}

When I was reading a book by Achmad Chodjim titled Annas: Segarkan Jiwa dengan Surah Manusia (lit. 'Reviving the Soul with Surah An-Nas ${ }^{1}$ ) for the first time, it really hit me on how it conveys a deep sense of tranquility aided of course through his eloquent analysis and presentation style. He begins with the definition of the words 'An-Nas' and 'Basyar' which mean 'mankind' or 'people'.

What makes this book enthralling rests on his unique understanding where he examines the notion that everything is based on ' $r a s a$ ' (lit. taste/feeling/instinct ${ }^{2}$ ). Taste in

\footnotetext{
${ }^{1}$ An-Nas is the Arabic word for mankind, people or human being.

2 The word 'rasa' derived from Sanskrit which means essence, taste or flavour. It can be roughly translated to English as taste or feeling. Whereas taste is more situated in an empirical domain; a chemical interaction that happens between any material and taste bud located in our tongue, while feeling is more of a nuance. Depending on certain cultural or religion practice, it can have spiritual or religious connotation.
} 
the scientific realm is one of the human five senses which can be attained via stimulation experienced by the tongue. Apart from the tongue, taste, or in this case, more suitably termed as feeling, can be achieved as a result of the complex process of human emotion such as love, hate, disgust, contempt, sadness and so forth. But these types of feelings are too vast to be discussed in this context. Hence, this paper will only concentrate on the concept of rasa that is associated with divinity.

The believers are only those who, when Allah is mentioned, their hearts become fearful, and when His verses are recited to them, it increases them in faith; and upon their Lord they rely.

(Quran, Al-Anfal 8:2)

Going through line by line in the above verse, we can find that there is a response from the heart when the name of Allah is mentioned. That reaction is jitter, an extreme anxiousness; a form of rasa. Referring from the above verse, the word 'mentioned' is a translation from the word zukira (ركذ). In fact, the word zukira derived from dzikr which means remember. Thus, the feeling of a trembling heart can be achieved by remembering Allah. We will not be able to remember Allah if we do not take an effort to know Him.

To know Allah, one must go through several journeys to gain knowledge. Knowledge here is the knowledge to get to know Allah. To learn about Allah should not be limited to only knowing His name, but one must be immersed in the essence of its hakikat (reality). It is a known fact that Allah's attribute is incomparable to anything. Thus, the only way to describe Allah's attribute is in the form of parables and metaphors.

Referring to the philosophy and mindset of the Malay culture and civilization, Allah's attribute is symbolized by the stem of the lotus. To represent the divinity, the lotus is chosen because its shape begins with a stem, a flower bud and a petal which is subject to their own meanings in explaining the knowledge of Allah.

\section{Research Methodology}

The humanities are among the academic disciplines that study human culture. The methods are primarily critical or speculative, and has a significant historical perspective. In humanities research, there are four types of methods that can be used such as literary and art criticism, philosophical research, artistic or creative practice as research. In this study, the researcher used the method of literary and art criticism. The definition of critical art or literary research is to use interpretations of a work of art or literature in the analysis, while investigating the complex context from which an artwork or literature has come to, in order to provide an understanding of how it fits into the larger realm of human experience.

Apart from that, the use of hermeneutics as a method that supports this humanities approach is also included. The use of hermeneutics as the methodology of interpretation is related when dealing with occurrences that arise through meaningful human actions and the products of such actions. Gadamer (2012) argued that an interpretation of past literature arises from the argument between the past and present, which can be associated closely. This theory has also been improvised through decades and is applied commonly in studies of text or literature as seen today. Therefore, hermeneutical methods and ideas have had a 
tremendous impact on phenomenology and it will continue to provide guidance for solving problems of interpretation of human actions, texts, and other meaningful material by offering a literary solution based on solid verifiable evidence.

In this study, the interpretation of the song lyrics Teratai is discussed from the philosophical perspective, which is associated with the Malay psyche through the meaning of rasa. The relation between the song lyrics which uses lotus flower as the symbol to represent divinity principles is then translated into spiritual connotation and understanding.

\section{Experience of Knowing Allah's Attribute in Lotus Flower}

The symbolic usage of lotus in explaining the concept of divinity leads to the creation of this particular song popularized by a legendary singer, Ramli Sarip. Entitled Teratai, this song gives a spiritual experience and rasa which the songwriter feels during his journey to know Allah.

\begin{tabular}{|c|c|}
\hline Oh teratai bunga indah & $\mathrm{O}^{\prime}$ the ever-lovely lotus \\
\hline Engkaulah pujaan hatiku & One that my heart worships \\
\hline Telah lama aku rindukan & I have long missed you \\
\hline Wahai teratai bunga indah & $\mathrm{O}^{\prime}$ the ever-lovely lotus \\
\hline Sungguh cantik wajahmu & Such a beauty you possess \\
\hline Sinar matamu bagaikan suria pagi & Your eyes sparkle like the morning sun \\
\hline Setiap insan selalu terpikat & It captures every man's heart \\
\hline \multirow[t]{2}{*}{ Memandang teratai bunga indah } & $\begin{array}{l}\text { Just by looking at you } \\
\mathrm{O}^{\prime} \text { the ever-lovely lotus }\end{array}$ \\
\hline & Never have I thought \\
\hline Ku tak menyangka & $\mathrm{O}^{\prime}$ my dear lotus \\
\hline Wahai terataiku sayang & It hits you like a hurricane \\
\hline Badai taufan mendatang & Storming you down \\
\hline Menghembus dirimu & and you withered \\
\hline Engkau pun terkulai & Losing your grace... \\
\hline \multicolumn{2}{|l|}{ Dan merunduklah layu... } \\
\hline & O’ please protect her \\
\hline Oh tolong, lindungilah dia & So that I can be with her again \\
\hline Agar kudapat bersamanya lagi & I long for my dear lotus \\
\hline Ku inginkan terataiku sayang & Blooming like a new beginning \\
\hline Berseri seperti semula & The ever-lovely lotus \\
\hline Teratai bunga indah & \\
\hline
\end{tabular}

Lotus in this lyric represents the principle which is held throughout the journey of knowing Allah. The song starts with praising lotus as a beautiful flower. Originally, lotus comes from a stem and it embodies the singularity of Allah's attribute and void from all beings. A stem is the holder of a flower, a symbolic foothold of the principle. Only from the stem can the flower be born. The new bud of a lotus signifies the combination of two of Allah's 
attributes which are jamal and jalal (in Arabic). Jamal means beautiful while jalal means glory. These are the praises which the songwriter would want to convey as the beauty of Allah.

For quite some time the songwriter has longed for the beauty of lotus. Symbolically, a human being has known and witnessed the existence of Allah while he is still in his mother's womb. This testimony is beautifully explained in the Quran:

And (mention) when your Lord took from the children of Adam - from their loins their descendants and made them testify of themselves, (saying to them), "Am I not your Lord?" They said, "Yes, we have testified." (This) - lest you should say on the day of Resurrection, "Indeed, we were of this unaware."

(Quran, Al-A'raf 7:172)

After witnessing Allah in the mother's womb, a man was born to Earth as a baby. Newborns naturally cry while clenching their fists. The idea of the babies clenching their fists is seen as they are holding on to this lotus' stem which symbolizes Allah' divinity that they acquired while they were in their mother's wombs. While going through adulthood, they slowly release the grip as they are enchanted with the worldly temporality. The beauty of lotus shines through the newborn's face, radiates like a morning sun ray - connoting the beginning of human life. Only those who are truly conscious that they are human being (insaan) can fully appreciate the beauty of lotus thus embrace the said divinity principle. This is the conclusion in the second stanza of the song lyrics.

If the stem symbolizes Allah's attribute, the petal born from the stem symbolizes the reality of Muhammadiyah. The reality of Muhammadiyah is the first reality that exists before the birth of the essence of everything. It can be said that it is also the reality of all beings. In a petal, it is filled with stamen, pistil, ovaries and so forth. Moreover, when a petal blooms, a stamen will bloom into a flower. Every petal personifies the different characteristic of every creature. The stem, however, will remain there along with the blooming flower. This points out that Allah's attribute exists in every creature.

A lotus returned to its original form complete with its bud and petal thus holding the stem means sticking with the singularity of Allah's attribute. By holding the stem, the whole divinity principle is in one's grip. If one only holds on to the petal which is the symbol of creature, the petal will wither and fall off. This is what happened when humans rely to just mere creatures which means they will hold on to something weak. Indeed, human easily makes mistakes. Numerous tests are given to human to scrutinize whether or not he can hold on firmly to the divinity principle.

The 'hurricane' in the third stanza of the song lyrics shows that there are many kinds of tests in the journey to know Allah. Sometimes, these unpredictable tests can make us more committed to our faith. But if unbearable, the lotus will wilt and no longer radiates its beauty as it used to. Thus, once we are in this stage, the only way out is to seek help from Allah, the One and Only. This help will ensure that we uphold the same divinity as the time we were born. This was also mentioned in the last line of the song lyrics where the songwriter prays that he can hold on to the divine principle until the end of his life. 


\section{Malay Culture and Symbolism}

The word 'Malay' which is pointed out to the general usage today is a name for one particular nation and language (Omar, 1985). The Malay concept as defined under the Malaysian constitution is one who speaks Malay, professes Islam and practices Malay's way of life. In addition to speaking Malay and practicing Malay culture, religion becomes a basis of acceptance whether he/she can or cannot be first acknowledged as a Malay person in Malaysia.

The Malays are the majority (ethnic group) in Malaysia followed by other races. The rights of Malay privileges are listed in the Malaysian constitution. One of them is the definition of being Malay which is citizenship and Islam. Malay and Islam cannot be separated. According to Article 160, a Malay must be a Muslim, but a Muslim does not necessarily be a Malay. If the Malay is fully committed to be Muslim, surely the Malay will always protect the dignity of Islam.

(Azmi, \& Ismadi, 2016)

The understanding of Malay and Islam is clearly stipulated in the above statement, which even supported in the Federal Constitution. Malay is famous for its rich culture. Culture in Malay is called budaya, a combination from these two words buddhi and daya. Buddhi is a loan word from Sanskrit which means intelligence and reason. While daya is a MalayPolinesian word which means a force, power and influence. These two words combined bring another meaning; a shape or to motivate human behavior (Balwi, 2005). Since this word is already adopted in Malay, the current meaning of culture that is being practiced today is civilization.

Apart from the culture, the 'Malay' also has unique characteristics by incorporating symbolism into the principles and philosophy. The root word for symbolism is symbol. Symbols convey the sign that represents linguistic entities and have been accepted in phonetic transcription and writing system. In this case, Malay symbolism uses lotus as a medium that carries multifaceted meanings. A symbol that becomes a focus in this research is the lotus. Its symbolism is still relevant to this day due to many people who are still holding on to the principle and philosophy imbued in it.

Symbolism that has become the foundation of the Malay's philosophy does not lie only in lotus. In fact, there are also other philosophies exemplified such as the moon and Wau $B u l a n^{3}$. The symbolism can be examined in the concept of nature, human body and nationalism which is the country. These philosophies are also associated with experience, religion (Islam), culture and the Malay race. Hence, Malay and symbolism cannot be separated due to the subtlety and rasa that remain perpetually in the society.

The symbolic of lotus is essentially different in every religion and culture in Malaysia. Generally, lotus symbolizes purity, enlightenment, self-regeneration and reincarnation. For example, referring to Buddhism, every human born into this world has the capacity to be a good human being and only time can bear witness. Just like lotus, it lives in a dirty and muddy

\footnotetext{
${ }^{3}$ Wau Bulan is one kind of traditional moon-kite that is commonly flown by men in Kelantan.
} 
water, but it is still able to bloom into a beautiful flower which outshines the gloomy, muddy and dirty area. Likewise, human should be capable to overcome the temporality of the material world.

\section{Conclusion}

Islam, Malay and symbolism have a distinct relationship in explaining the feeling and experience of Teratai's songwriter. Islam which has long existed in this region has permeated into every sphere of Malay's culture, principle and philosophy. A Malay who wishes to learn more about Islam should first learn about Allah. In the process of knowing Him, many experiences and feelings are gained. But to let others know about the process is often disputable. Undeniably, there are certain challenges and problems faced throughout the experiences. Hence, humans use as many possible mediums to convey their messages because the Malay culture is rich in principles, philosophies and symbolism. Therefore, the song Teratai is taken to symbolize Allah's attribute.

The songwriter carefully selected the characteristics of lotus in telling the audience about the experience and the feelings he gained. Song lyrics are the most effective medium to communicate the experience of the songwriter. However, the study on this lyric is based on the previous study and also from the researcher's own experience. It is not considered erroneous as long as the experience that one gained is similar to everyone else. For example, one of the features of sugar is its sweetness. Everyone who tastes sugar will get the same sweet taste. It is unlikely for someone who tasted the sugar to find it salty. In this context of research, the songwriter and researcher attempt to be mindful of the feeling to know the one true Allah.

The significance of this matter to the Malays is that they exercise their daily practices and experiences as the guidance and philosophy of life. This is to demonstrate that only by experiencing, one can tell the stories. Although the stories have been passed verbally, the influence is still present in the society to this day. One of the remarkable tools to use is the teksdialisme theory, which defines that there is no restriction in interpreting an experience because the level of a person's rasa is contradictory and never the same.

Another analogy given is about the sky. The sky has seven layers and to each its own event. The interpretation of the 'sky' here does not refer to the literal sky on Earth, but it denotes to the discipline of knowledge. In order to understand the symbols, one must essentially experience 'going through the sky'. The obvious statement from this paper is that each individual must be obliged to life principles that have been promised by Allah. Islam is a religion of blessings. Therefore, the principles that we hold on to must be experienced. Take lotus for an example as a guideline for life to experience and rasa. 


\section{References}

Anonymous (n.d.). The symbolic meaning of the lotus flower. New York: Institute for Asia and Asian Diasporas, Binghamton University.

Azmi, N. N., \& Ismadi, W. A. A. M. (2016). Sisi semantik dalam memahami konsep ketuhanan: Kajian lirik lagu melayu terpilih. Seminar Antarabangsa ke-5, Arkeologi, Sejarah dan Budaya di Alam Melayu, 1:176-183.

Balwi, M. K. M. (2005). Peradaban melayu. Johor: Penerbit UTM Press.

Chodjim, A. (2004). Annas: Segarkan jiwa dengan surah manusia. Jakarta: PT Serambi IImu Semesta.

Sikana, M. (2013). Berdiri di akar diri: Kritikan sastera melayu pascamoden. Arah Tuju Teori dan Kritikan Sastera Melayu Pascamoden. Kuala Lumpur: Institut Terjemahan dan Buku Malaysia.

Mohamed, A. (1978). Falsafah dan pemikiran orang-orang melayu. Kuala Lumpur: Kementerian Kebudayaan, Belia dan Sukan Malaysia.

Omar, A. H. (1985). Susur galur bahasa melayu. Kuala Lumpur: Dewan Bahasa dan Pustaka

Regan, P. (2012). Hans-Georg Gadamer's philosophical hermeneutics: Concepts of reading, understanding, and interpretation. META: Research in Hermeneutics, Phenomenology, and Practical Philosophy, 4:286-303.

Terjemahan al-Quran al-Karim. (Mansor, M. N., Trans.). (2019). Al-Hidayah House of Quran Sdn Bhd. 